\title{
1 Ar-Ar age constraints on the timing of Havre Trough opening and
}

2 magmatism.

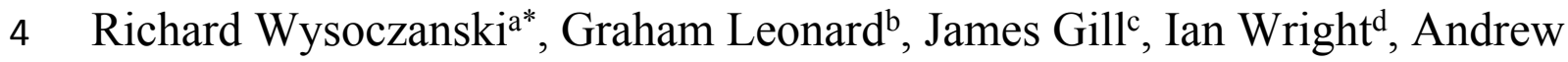

5 Calvert $^{\mathrm{e}}$, William McIntosh ${ }^{\mathrm{f}}$, Brian Jicha ${ }^{\mathrm{g}}$, John Gamble ${ }^{\text {hi }}$, Christian Timm ${ }^{\mathrm{b}, \mathrm{j}}$, 6 Monica Handler $^{\mathrm{h}}$, Elizabeth Drewes ${ }^{\mathrm{k}}$, and Alex Zohrab ${ }^{\mathrm{h}}$.

7

8 9 Zealand Zealand Germany

\section{Abstract}

${ }^{a}$ National Institute of Water \& Atmospheric Research, Private Bag 14901, Wellington, New

${ }^{b}$ GNS Science, 1 Fairway Drive, Avalon, Lower Hutt, New Zealand

${ }^{c}$ Department of Earth and Planetary Sciences, University of California, Santa Cruz, California, USA

${ }^{d}$ Vice Chancellor's Office, University of Canterbury, Private Bag 4800, Christchurch 8141, New Zealand

eVolcano Science Center, US Geological Survey, Menlo Park, California, USA

${ }^{f_{N}}$ ew Mexico Geochronology Research Laboratory, New Mexico Tech, Socorro, USA

${ }^{g}$ Department of Geoscience, University of Wisconsin-Madison, 1215 West Dayton Street, Madison WI 53706

${ }^{h}$ School of Geography, Environment \& Earth Science, Victoria University of Wellington, New

${ }^{i}$ School of Biological, Earth \& Environment Sciences, University College Cork, Ireland ${ }^{j}$ GEOMAR, Helmholtz Centre for Ocean Research, RD 4, Wischhofstrasse 1-3, 24148 Kiel,

${ }^{k}$ Alaska Science Center, Alaska Science Center, U.S. Geological Survey, 4210 University Drive, Anchorage, AK 99508, USA

The age and style of opening of the Havre Trough back-arc system is uncertain due to a lack of geochronologic constraints for the region. ${ }^{40} \mathrm{Ar} /{ }^{39} \mathrm{Ar}$ dating of 19 volcanic rocks from across the southern Havre Trough and Kermadec Arc was conducted in three laboratories to provide age constraints on the system. The results are integrated and interpreted as suggesting that this subduction system is young $(<2 \mathrm{Ma})$ and coeval with opening of the continental 
Taupo Volcanic Zone of New Zealand. Arc magmatism was broadly concurrent across the breadth of the Havre Trough.

\section{Keywords}

Havre Trough, Kermadec Arc, Ar-Ar, magmatism, back-arc basin, rifting

\section{Introduction}

The present-day Kermadec Arc and associated Havre Trough back-arc basin is the youngest in a series of Cenozoic volcanic arcs that have developed along the northern New Zealand margin in response to convergence of the Pacific and Australian Plates (Mortimer et al., 2010; Herzer et al., 2011; Bassett et al., 2016). The Kermadec Arc - Havre Trough (KAHT) subduction system is the central portion of a contiguous arc system, with the Tonga Arc Lau Basin back-arc system to the north, and the Taupo Volcanic Zone (TVZ) of continental New Zealand to the south (Figure 1) (Smith and Price, 2006). The predecessor to the Kermadec Arc, the Miocene-Pliocene Colville Arc (Skinner, 1986; Ballance et al., 1999), rifted apart in response to rollback of the Pacific Plate (Sdrolias and Muller, 2006; Wallace et al., 2009), forming the Havre Trough and resulting in the establishment of the modern Kermadec Arc front. The Colville Ridge and Kermadec Ridge are the remnants of the Colville Arc (Figure 1).

The age of opening of the Havre Trough and establishment of the Kermadec Arc is not clear owing to a paucity of age data. In part, this is due to the inherent difficulty in obtaining reliable radioisotopic ages on young, glassy, and vesicular submarine volcanic rocks with low potassium content, and in part due to tectonic complexity, and until recently, limited seafloor sampling in the region. Here, we present ${ }^{40} \mathrm{Ar}-{ }^{39} \mathrm{Ar}$ ages on seafloor volcanic samples from across the southern KAHT subduction system that have important implications for both the age and style of opening of the Havre Trough.

\section{Models for opening of the Havre Trough}

Several models have been proposed to explain the tectono-magmatic evolution of the Havre Trough and Kermadec Arc, but the process and timing of opening remains contentious. Malahoff et al. (1982), based on airborne magnetic studies and seismic lines over the southern and central portions of the KAHT, tentatively interpreted the Havre Trough to be undergoing spreading, centred on an axial ridge. They interpreted residual magnetic 
anomalies to indicate a ca. 1.8 Ma age of opening of the basin. Wright (1993), however, interpreted swath mapping data as showing that at least the southern Havre Trough lacked a medial spreading ridge, and hence interpreted back-arc rifting rather than spreading as the mode of extension. Further, Wright (1993), suggested that initiation of rifting occurred at ca. $5 \mathrm{Ma}$, although this age was constrained by extrapolation of geodetic data on continental New Zealand rather than on direct age data from within the Havre Trough.

Subsequent models for Havre Trough opening agreed that the system was rifting but have varied in the process and style of rifting being proposed. Wright et al. (1996) suggested that Havre Trough opening and magmatism progressed eastward with time. Parson and Wright (1996) further argued that there was a latitudinal progression from full oceanic spreading in the Lau Basin to the north, to basin rifting in the TVZ to the south. The southern Havre Trough was considered to be in an intermediate phase of rifting that was concentrated along the axial zone of the trough. Ruellan et al. (2003), on the basis of multibeam bathymetry and seismic reflection data, concluded that the southward propagation of spreading was oversimplified, and that southward migration of subduction of the Louisville Seamount Chain had effectively locked the KAHT. They proposed that opening of the Havre Trough was initially fast and pervasive, and then relatively quiescent as the system became locked. Wysoczanski et al. (2010), on the basis of morphological similarities, suggested that the Havre Trough was in a similar state of rifting to the Valu Fa Ridge and Western Lau Basin, and that it also was in a state of "disorganised spreading" (Martinez and Taylor, 2006) whereby diffuse patches of extension localised in deep rifts precedes longitudinally traceable axial ridges characteristic of true ocean spreading systems. This model reconciled the oceanic spreading model of Malahoff et al. (1982) with models of rifting, and is similar to the Parson and Wright (1996) final stage of rifting (their "Phase 4") preceding full spreading.

\section{Analytical Methods and Results}

A total of 19 volcanic rocks of variable composition dredged from across the KAHT (Table 1) have been dated by Ar-Ar step heating. The sample set is diverse, including samples from five arc front volcanoes, two volcanoes in the central Havre Trough (Gill and Rapuhia), a deep central Havre Trough basin (Ngatoro Rift) with a short axial ridge in its southern extent, and a cross-arc seamount chain (Rumble V Ridge) that spans the breadth of the Havre Trough, from Rumble V to the Colville Ridge (Figure 2). Geochemical data for all the samples have previously been reported, and the source of those data, together with new Ar- 
Ar ages presented here, are shown in Table 1. With the exception of one andesite and one dacite from the volcanic arc front, all samples are basalts or basaltic andesites (Figure 3).

Ar-Ar analyses were performed in three laboratories (USGS, Menlo Park; New Mexico Institute of Mining and Technology (NMIMT), Socorro; and University of Wisconsin-Madison), initially as four smaller and separate studies. The datasets are combined here as one larger study to place constraints on the age of the KAHT (Table 1, Figure 2). All ages presented in Table 1 include $2 \sigma$ uncertainties and full details of the analytical techniques are given in the Supplementary File.

The majority of ages for the arc front volcanoes are $<0.06 \mathrm{Ma}$, although two samples, from Clark (C/1) and Rumble III (X333) have slightly older mean ages of $0.11 \mathrm{Ma}$ and 0.12 Ma respectively. Uncertainties on arc front samples however are large, with most ages having $2 \sigma$ uncertainties of zero age, and most ages are zero within analytical uncertainty.

Three samples from Rumble V Ridge have ages of $<0.11 \mathrm{Ma}$, overlapping those of the arc front volcanoes within uncertainty. The Ngatoro Rift samples have older ages between $0.20 \mathrm{Ma}$ and $0.68 \mathrm{Ma}$.

To the north, two samples from Rapuhia Ridge, a volcanic ridge extending southwest from Rapuhia volcano in the centre of the Havre Trough, yielded ages of $0.05 \pm 0.05 \mathrm{Ma}$ and $0.11 \pm 0.03 \mathrm{Ma}$. These ages are marginally older than, but within error of, ages derived from the active volcanic arc front. They are on average younger than the samples from Rumble $\mathrm{V}$ Ridge [see above], and notably younger than most of the Ngatoro Rift samples. Three samples analysed from Gill volcano, a back-arc volcano in the Havre Trough that lies between Rapuhia Ridge and the Colville Ridge (Figure 1), have ages significantly older than all other samples, at $0.88 \pm 0.05 \mathrm{Ma}, 0.97 \pm 0.03 \mathrm{Ma}$ and $1.19 \pm 0.04 \mathrm{Ma}$.

\section{Discussion}

The presented Ar-Ar ages are from samples that span almost the entire width of the southern Havre Trough and thus provide important constraints on the manner and timing of its opening.

A first order observation is that the oldest ages reported here, from a back-arc stratovolcano (Gill volcano: Wysoczanski et al., 2010) in the western part of the Havre Trough, are 0.9 - 1.2 Ma (Table 1, Figure 2). However, because Gill volcano sits on a rifted basin floor, the implied age of rifting must be older. This age is similar to a preferred Ar-Ar age of $1.1 \pm 0.4$ Ma reported for a basalt from the western Havre Trough (Mortimer et al., 
2007) sampled $450 \mathrm{~km}$ to the north of, and along strike from, Gill volcano, and to a $1.25 \pm$ $0.06 \mathrm{Ma} \mathrm{U}-\mathrm{Pb}$ zircon age from a tonalite xenolith from Raoul Island (Mortimer et al., 2010). In addition, Mortimer et al. (2007) reported an Ar-Ar age of $1.2 \mathrm{Ma} \pm 0.8$ for a basalt from the Northland Plateau (Figure 1), which they considered to be related to westernmost Colville Ridge volcanism. Together, these ages show no evidence for magmatic activity in the Havre Trough before c. 1.2 Ma, and as noted by Mortimer et al. (2010) suggest that magmatism was active across the full width of the KAHT and west of the Colville Ridge at this time (Figure 2). Furthermore, one of our plateau ages from Gill volcano is $875 \pm 50 \mathrm{ka}$, and thus it is conceivable that the age of magmatism for the Havre Trough is younger than 1.2 Ma, and possibly $<1$ Ma.

Using the 19 new Ar/Ar ages presented in this study and two previously reported by Mortimer et al. (2007; 2010), we now have sufficient geochronologic data to interpret the age of the Havre Trough. In addition, Ballance et al. (1999) reported eight K-Ar ages of c. 2 Ma or younger for the Kermadec Ridge and three K-Ar ages from the eastern Havre Trough, which were near zero age (the oldest at $0.15 \pm 0.12 \mathrm{Ma}$ ). These ages for the Havre Trough are all significantly younger than the c. 5 Ma age of rifting proposed by Wright (1993). However, we note that all current age data are from surficial seafloor volcanics, and future sampling (especially from sub-seafloor drilling) may yield older ages that would require a reinterpretation of the results presented here.

The young age of magmatism, if correct, provides three important implications for the tectonic development of the Havre Trough.

Firstly, magmatism and translocation of the modern Kermadec Arc front did not occur in a monotonic eastward progression. Notably, there is near- zero age arc magmatism in the central portion of the Havre Trough at Rapuhia Ridge, and magmatism related to Rumble V Ridge does not young to the east (Figure 4). The Rumble V Ridge dates are younger in age than the Ngatoro Rift, indicating that the ridge may have been constructed over the Ngatoro Rift (and if this is correct, also the Rumble Rift), rather than being cut by rifting as previously suggested (Wright et al., 1996).

Second, reported age data for the Havre Trough is $<1.2 \mathrm{Ma}$, and possibly $<1 \mathrm{Ma}$. This is younger than, but broadly consistent with, the $1.8 \mathrm{Ma}$ age of rifting suggested by Malahoff et al. (1982), although that model assumed a full spreading centre, whereas more recent tectonic models based on seafloor morphology suggest that the Havre Trough is comprised of a number of rifts and basal plateaus (e.g. Wright, 1993; Wysoczanski et al., 2010; Wysoczanski and Clark, 2012). These ages infer a c. 2.5-4 x faster extension rate for 
the Havre Trough than the $15-20 \mathrm{~mm} \mathrm{yr}^{-1}$ rate suggested by Wright (1993). An age of $2 \mathrm{Ma}$ would give an average rate of c. $40-50 \mathrm{~mm} \mathrm{yr}^{-1}$. Whilst reasonably fast, this rate is not unusual for extension rates in other intra-oceanic back-arc rifts, and is still significantly slower than the full ocean spreading rates of $>100 \mathrm{~mm} \mathrm{yr}^{-1}$ occurring in the Lau Basin and Manus Basin (e.g. Taylor and Martinez, 2003; Heuret \&Lallemand, 2005; Wallace et al., 2005). Notably this is similar to the extension rate of c. $40-60 \mathrm{~mm} \mathrm{yr}^{-1}$ seen at the southern portion of the Lau Basin (Parson and Wright, 1996; Martinez and Taylor, 2001).

Third, opening of the Havre Trough is coeval with initiation of TVZ magmatism and rifting at c. $2 \mathrm{Ma}$ (Wilson et al., 1995) and the TVZ rift and Havre Trough are the continental and oceanic expression of the same rift system (e.g. Parson and Wright, 1996). It is unclear if rifting was occurring prior to c. 2 Ma onshore in New Zealand: 1.8-3.9 Ma volcanism occurred along the Maungatautari-Kaimai-Tauranga alignment parallel to but northwest of the TVZ, as eruptions migrated southeast from the Coromandel area (Briggs et al., 2005). Given our ages for the Havre Trough, and that the youngest reported age of volcanism from the Colville Ridge is $2.6 \mathrm{Ma}$ (Timm et al., in review), this magmatism is more likely to be related to Colville Arc magmatism rather than Havre Trough magmatism.

The western portion of the TVZ is the oldest part of that system (the "old TVZ" of Wilson et al., 1995, and Wilson and Rowland, 2016), and rifting is now focussed more to the east and along a central rift, variously defined as the "young TVZ" and "modern TVZ" (Wilson et al., 1995; Wilson and Rowland, 2016), Ruaumoko Rift (Rowland and Sibson, 2001) and the Taupo Rift (Villamor and Berryman, 2006). Whilst young arc magmatism is broadly occurring across the Havre Trough (Figure 4) we have insufficient data to identify any age progression of rift-related magmatism across the Havre Trough. It remains uncertain if eastern Havre Trough rift magmatism is younger than western Havre Trough rift magmatism, and so akin to the old and young/modern TVZ regions, respectively.

The present state of extension/rifting of the Havre Trough remains uncertain. In the case of the Ngatoro Rift, the ages presented here indicate prolonged magmatism over at least $0.4 \mathrm{Ma}$, and that the rift is not presently magmatically active at the seafloor. Importantly though there is extensive shallow seismic activity $(<13 \mathrm{~km}$ deep) within the Ngatoro Rift (de Ronde et al., 2007). Regional moment tensor analysis for recent (2003-2012) shallow $(<33$ $\mathrm{km}$ ) earthquakes in the southern Havre Trough show extension as well as strike slip movement (Ristau, 2014). At first order the shallow extensional seismicity in the Ngatoro Rift and elsewhere in the Havre Trough indicates present-day extension / rifting of the trough. Magmatic rift intrusives (e.g., dykes) may also be contemporaneous, however the 
200

201

202

203

204

205

206

207

208

209

210

211

212

213

214

215

216

217

218

219

220

221

222

223

224

225

226

227

228

229

230

231

absence of present day surficial extrusives and lack of hydrothermal activity suggests that seafloor, or near seafloor, rift magmatism is not occurring at the present day.

\section{Conclusions}

New Ar-Ar ages presented here, coupled with other published radioisotopic ages from the literature (Ballance et al., 1999; Mortimer et al., 2007, 2010), suggest that opening of the Havre Trough initiated < c. 2 Ma, and perhaps as recently as c. 1 Ma. The oldest ages occur on the margins of the basin and significant young arc magmatism occurred across the central Havre Trough. The timing of initiation of magmatism is coeval with that of the TVZ. The caveat to our age constraints is that all samples are surficial and there are no ages for samples within c. $25 \mathrm{~km}$ of the Colville Ridge (Figure 4).

Our results show that there has been arc and rift-related magmatism across the entire southern Havre Trough within the last c. 1 Ma, both within rifts (e.g., Ngatoro Rift) and constructing large stratovolcano cones such as Gill and seamounts of Rumble V Ridge (Wright e al., 1996; Todd et al., 2010). This, together with the $>4 \mathrm{~km}$ water depth in the deepest parts of the basin, is more consistent with distributed rifting across the basin than ocean spreading. Whether there are differences in age between rift-related magmas erupted at different depths, or distance across the basin, or distance northward from New Zealand, is important for understanding the tectonic evolution of the basin but remains to be discovered. Our experience shows that ${ }^{40} \mathrm{Ar} /{ }^{39} \mathrm{Ar}$ ages can be obtained for the challenging Havre Trough samples, but that sample selection and treatment are important considerations.

\section{Acknowledgements}

The authors would like to thank Erin Todd for his internal review, and Roger Briggs and an anonymous reviewer for their helpful reviews. RW was funded by the Ministry of Business, Innovation and Employment (MBIE) Strategic Science Investment Fund (SSIF) programme Marine Geological Processes and Resources (COPR1902). CT received funding from the European Union's Horizon 2020 research and innovation programme under the Marie Skłodowska-Curie grant agreement \#79308.

\section{References}


232 Ballance PF, Ablaev AG, Pushchin IK, Pletnev SP, Birylina MG, Itaya T, Follas HA, Gibson, 233 GW. 1999. Morphology and history of the Kermadec trench-arc-backarc basin-remnant arc

234

235

236

237

238

239

240

241

242

243

244

245

246

247

248

249

250

251

252

253

254

255

256

257

258

259

260

261

262

263

264

system at 30 to $32^{\circ} \mathrm{S}$ : geophysical profile, microfossil and $\mathrm{K}-\mathrm{Ar}$ data. Marine Geology. 159:35-62.

Bassett D, Kopp H, Sutherland R, Henrys S, Watts AB, Timm C, Scherwath M, Grevemeyer I, de Ronde CEJ. 2016. Crustal structure of the Kermadec arc from MANGO seismic refraction profiles. Journal of Geophysical Research. 121:7514-7546.

Briggs RM, Houghton BF, McWilliams M, Wilson CJN. 2005. ${ }^{40} \mathrm{Ar} /{ }^{39} \mathrm{Ar}$ ages of silicic volcanic rocks in the Tauranga-Kaimai area, New Zealand: Dating the transition between volcanism in the Coromandel Arc and the Taupo Volcanic Zone. New Zealand Journal of Geology and Geophysics. 48:459-469.

DeMets C, Gordon RG, Argus DF. 2010. Geologically current plate motions. Geophysical Journal International. 181(1):1-80.

de Ronde CEJ, Baker ET, Massoth GJ, Lupton JE, Wright IC, Sparks RJ, Bannister SC, Reyners ME, Walker SL, Greene RR, Ishibashi J, Faure K, Resing JA, Lebon GT. 2007. Submarine hydrothermal activity along the mid-Kermadec Arc, New Zealand: Large-scale effects on venting. Geochemistry Geophysics Geosystems. 8. Q07007, doi: 10.1029/2006GC001495.

Gamble JA, Wright IC, Baker JA. 1993. Seafloor geology and petrology in the oceanic to continental transition zone of the Kermadec-Havre-Taupo Volcanic Zone arc system, New Zealand. New Zealand Journal of Geology and Geophysics. 36:417-435.

Gamble JA, Christie HK, Wright I, Wysoczanski R. 1997. Primitive K-rich magmas from Clark volcano, southern Kermadec Arc: A paradox in the $\mathrm{K}-$ depth relationship. The Canadian Mineralogist. 35:275-290.

Herzer RH, Barker DHN, Roest WR, Mortimer N. 2011. Oligocene-Miocene spreading history of the northern South Fiji Basin and implications for the evolution of the New 
265 Zealand plate boundary. Geochemistry, Geophysics, Geosystems. 12. Q02004,

266

267

268

269

270

271

272

273

274

275

276

277

278

279

280

281

282

283

284

285

286

287

288

289

290

291

292

293

294

295

296

297

doi:10.1029/2010GC003291.

Heuret A, Lallemand S. 2005. Plate motions, slab dynamics and back-arc deformation.

Physics of the Earth and Planetary Interiors. 149:31-51

Malahoff A, Feden R, Fleming H. 1982. Magnetic anomalies and tectonic fabric of marginal basins north of New Zealand. Journal of Geophysical Research. 87:4109-4125.

Martinez F, Taylor B. 2001. Mantle wedge control on back-arc crustal accretion. Nature. 416:417-420.

Martinez F, Taylor B. 2006. Modes of crustal accretion in back-arc basins: inferences from the Lau Basin. In: Christie DM, Fisher CR, Lee S-M, Givens S, editors. Back- arc Spreading Systems: Geological, Biological, Chemical and Physical Interactions. Geophysical Monograph Series 166. American Geophysical Union. p. 5-30.

Mortimer N, Gans PB, Palin JM, Meffre S, Herzer RH, Skinner DNB. 2010. Location and migration of Miocene-Quaternary volcanic arcs in the SW Pacific region. Journal of Volcanology and Geothermal Research. 190:1-10.

Mortimer N, Herzer RH, Gans PB, Laporte-Magoni C, Calvert AT, Bosch D. 2007. Oligocene-Miocene tectonic evolution of the South Fiji Basin and Northland Plateau, SW Pacific Ocean: evidence from petrology and dating of dredged rocks. Marine Geology. 237:1-24.

Parson LM, Wright IC, 1996. The Lau-Havre-Taupo back-arc basin: a southward propagating, multi-stage, evolution from rifting to spreading. Tectonophysics. 263:1-22.

Ristau J. 2014. Update of Regional Moment Tensor Analysis for Earthquakes in New Zealand and Adjacent Offshore Regions. Bulletin of the Seismological Society of America. $103: 2520-2533$. 
298 Ruellan E, Delteil J, Wright I, Matsumoto T. 2003. From rifting to spreading in the Lau Basin

299 - Havre Trough backarc system (SW Pacific) - locking/unlocking induced by ridge

300 subduction. Geochemistry, Geophysics, Geosystems. 7. doi:10.1029/2001GC000261.

301

302 Rowland JV, Sibson RH. 2001. Extensional fault kinematics within the Taupo Volcanic

303 Zone, New Zealand: soft-linked segmentation of a continental rift system. New Zealand

304 Journal of Geology and Geophysics. 44:271-283.

305

306 Sdrolias M, Muller RD. 2006. Controls on back-arc formation. Geochemistry, Geophysics,

307 Geosystems. 7. Q04016, doi:10.1029/2005GC001090.

308

309 Skinner DNB. 1986. Neogene volcanism of the Hauraki Volcanic Region. Royal Society of

310 New Zealand Bulletin. 23:21-47.

311

312 Smith IEM, Price RC. 2006. The Tonga-Kermadec arc and Havre-Lau back-arc system: Their

313 role in the development of tectonic and magmatic models for the western Pacific. Journal of

314 Volcanology and Geothermal Research. 156:315-331.

315

316 Taylor B, Martinez F. 2003. Back-arc basin basalt systematics. Earth and Planetary Science

317 Letters. 210:481-497.

318

319 Timm C, de Ronde CEJ, Hoernle K, Cousens B, Wartho J-A, Caratori Tontini F,

320 Wysoczanski R, Hauff F, Handler M. Accepted. Colville and Kermadec Ridges, SW Pacific:

321 new radiometric age data and insights into the recent geological history and petrogenesis of

322 northern Zealandia. Gondwana Research.

323

324 Todd E, Gill JB, Wysoczanski RJ, Handler MR, Wright IC, Gamble JA. 2010. Sources of

325 constructional cross-chain volcanism in the southern Havre Trough: New insights from HFSE

326 and REE concentration and isotope systematics. Geochemistry, Geophysics, Geosystems. 11.

327 Q04009, doi:10.1029/2009GC002888.

328

329 Todd E, Gill JB, Wysoczanski RJ, Hergt J, Wright IC, Leybourne MI, Mortimer, N. 2011. Hf

330 isotopic evidence for small-scale heterogeneity in the mode of mantle wedge enrichment: 
331 Southern Havre Trough and South Fiji Basin back-arcs. Geochemistry, Geophysics,

Geosystems. 11. Q09011, doi:10.1029/2011GC003683.

333

Villamor P, Berryman KR. 2006. Evolution of the southern termination of the Taupo Rift,

New Zealand. New Zealand Journal of Geology and Geophysics. 49:23-37.

Wallace LM, McCaffrey R, Beavan J, Ellis S. 2005. Rapid microplate rotations and backarc rifting at the transition between collision and subduction. Geology. 33:857-860.

Wallace LM, Ellis S, Mann P. 2009. Collisional model for rapid fore-arc block rotations, arc curvature, and episodic back-arc rifting in subduction settings. Geochemistry, Geophysics,

Geosystems. 10. Q05001, doi:10.1029/2008GC002220.

Wilson CJN, Houghton BF, McWilliams MO, Lanphere MA, Weaver SD, Briggs RM. 1995.

Volcanic and structural evolution of Taupo Volcanic Zone, New Zealand: a review. Journal of Volcanology and Geothermal Research. 68:1-28.

Wilson CJN, Rowland JV. 2016. The volcanic, magmatic and tectonic setting of the Taupo

Volcanic Zone, New Zealand, reviewed from a geothermal perspective. Geothermics. 59:168-187.

Wright IC. 1993. Pre-spread rifting and heterogeneous volcanism in the southern Havre Trough back-arc basin. Marine Geology. 113:179-200.

Wright IC, Parson LM, Gamble JA. 1996. Evolution and interaction of migrating cross-arc volcanism and backarc rifting: an example from the southern Havre Trough $\left(35^{\circ} 20^{\prime}-37^{\circ} \mathrm{S}\right)$. Journal of Geophysical Research. 101:22071-22086.

Wysoczanski R, Clark M. 2012. Southern Kermadec Arc - Havre Trough Geohabitats. In: Harri, P, Baker E, editors. Seafloor Geomorphology as Benthic Habitat: Geohab Atlas of Seafloor Geomorphic Features and Benthic Habitats. Elsevier. p. 853-867. 
365 Havre Trough backarc rifts (SW Pacific). Journal of Volcanology and Geothermal Research.

366

367

368

369

370

371

\section{$372 \quad$ Figures}

373

374

375

376

377

378

379

380

381

382

383

384

385

386

387

388

389

390

391

392

393

394

395

396

397 Wellington. (Table 1).

Zohrab A. 2017. The petrology, geochemistry and geochronology of back-arc stratovolcanoes in the southern Kermadec Arc-Havre Trough, SW Pacific. MSc. Victoria University of

Figure 1: Tectonic setting of New Zealand and the SW Pacific highlighting the Kermadec Arc - Havre Trough (KAHT), the Tonga-Lau subduction system, and the Taupo Volcanic Zone (TVZ) of continental New Zealand (red outline). Black arrow is the relative motion of the Pacific Plate to a fixed Australian Plate for the southern KAHT region (DeMets et al., 2010). HP = Hikurangi Plateau, Louisville $\mathrm{SC}=$ Louisville Seamount Chain, NP $=$ Northland Plateau, VFR = Valu Fa Ridge. Red triangles denote oceanic volcanoes of the Kermadec Arc and Havre Trough, and the offshore TVZ (southernmost volcano, Whakatane). Highlighted area is that of Figure 2.

Figure 2: Bathymetric map of the southern KAHT system, bounded by the Colville Ridge to the west and the Kermadec Ridge to the east. Depths on the bathymetry scale are metres below sea level, with depths $<1500 \mathrm{~m}$ shown as $1500 \mathrm{~m}$ and depths $>3500 \mathrm{~m}$ shown as 3500 $\mathrm{m}$. Orange triangles are volcanoes: $\mathrm{C}=$ Clark, $\mathrm{G}=\mathrm{Gill}, \mathrm{R}=$ Rapuhia, $\mathrm{RIII}=$ Rumble III, $\mathrm{RIV}$ $=$ Rumble IV, RV $=$ Rumble $\mathrm{V}, \mathrm{T}=$ Tangaroa. Numbers in boxes denote new Ar/Ar ages

Figure 3: Silica content of samples analysed in this study with distance from the crest of the Kermadec Ridge.

Figure 4: Ar/Ar ages of Havre Trough samples (Table 1) with distance from the Kermadec Ridge crest. Error bars show 2 sigma uncertainties. Black diamonds are K/Ar ages of Ballance et al. (1999) from Kermadec Ridge and Havre Trough samples at least $300 \mathrm{~km}$ north of samples presented here. Grey square at $\sim 80 \mathrm{~km}$ is an Ar/Ar preferred age for a basalt from the Havre Trough (Mortimer et al., 2007). Grey square at $0 \mathrm{~km}$ is a U-Pb age of zircon from a 
398 tonalite from Raoul volcano (Mortimer et al., 2010), $600 \mathrm{~km}$ to the north of the study area, 399 where the modern arc front sits on the Kermadec Ridge (Figure 1).

400

401 Table

402

403 Table 1: Details of samples analysed in this study. Ages are: $\mathrm{P}=$ plateau ages, $\mathrm{I}=$ Isochron 404 ages, $\mathrm{R}=$ Recoil age (see Supplementary File for details). Supplementary File contains plateau 405 and isochron ages and plots, experimental data including K/Ca ratio, MSWDs, number of 406 steps, and total gas age; along with an explanation of experimental methods and machine data 407 for individual heating steps within each experiment. Results have been recalculated to a 408 consistent fluence monitor age equivalent to Fish Canyon sanidine at 28.198 Ma (Menlo 409 Park) and at 28.201 Ma (NMIMT). All errors are 2б. For four samples, X379, X690, X682, 410 and $\mathrm{X} 696$ the mean age is negative, so the positive fraction of the age is reported as a 411 maximum value (i.e. $<x x$ Ma), calculated as the mean of the $2 \sigma$ error. IGSN numbers are 412 given for those samples that have been assigned numbers. Reference for geochemical 413 analyses: 1, Gamble et al, 1997; 2, Wright and Gamble, unpublished data; 3, Gamble et al., 414 1993; 4, Todd et al., 2010; 5, Zohrab, 2017; 6, Todd et al., 2011. All geochemical data are 415 reported as anhydrous, with $\mathrm{Fe}$ as $\mathrm{FeO}_{\text {total }}$. 


\begin{tabular}{|c|c|c|c|c|c|c|c|c|c|c|c|c|c|}
\hline STATION & LOCATION & $\begin{array}{l}\text { LATITUDE } \\
\text { SOUTH }\end{array}$ & $\begin{array}{c}\text { LONGITUDE } \\
\text { EAST }\end{array}$ & $\begin{array}{c}\text { DEPTH } \\
M\end{array}$ & LAB & LAB NO. & IGSN & REF. & $\begin{array}{c}\mathrm{SiO}_{2} \\
\mathrm{WT} . \%\end{array}$ & $\begin{array}{l}\text { MgO } \\
\text { WT.\% }\end{array}$ & $\begin{array}{c}\mathrm{K}_{2} \mathrm{O} \\
\mathrm{WT} . \%\end{array}$ & AGE Ma & \\
\hline $\mathrm{C} / 1$ & Clark & 36.416 & 177.848 & 2040 & NMIMT & Clark \#45, 6696 & & 2 & 50.75 & 9.46 & 1.57 & $0.11 \pm 0.05$ & $\mathrm{P}$ \\
\hline X299 & Rumble III & 35.749 & 178.498 & 717 & NMIMT & Rumble III \#1, 6692 & & 2 & 52.61 & 4.44 & 0.58 & $0.04 \pm 0.06$ & $\mathrm{P}$ \\
\hline X333 & Rumble III & 35.715 & 178.528 & 565 & NMIMT & Rumble III \#8, 6695 & & 2 & 52.14 & 6.72 & 0.48 & $0.12 \pm 0.08$ & $\mathrm{P}$ \\
\hline X351 & Rumble IV & 36.131 & 178.024 & 1258 & NMIMT & Rumble IV \#9, 6703 & & 2 & 66.19 & 1.47 & 1.11 & $0.03 \pm 0.02$ & $\mathrm{P}$ \\
\hline X379 & Rumble V & 36.153 & 178.161 & 1619 & NMIMT & Rumble V\#23, 6694 & JBG000010 & 2 & 54.00 & 3.51 & 0.60 & $<0.03$ & $\mathrm{P}$ \\
\hline$X 407$ & Rumble V & 36.133 & 178.202 & 750 & NMIMT & Rumble V \#26, 6704 & & 2 & 53.95 & 3.52 & 0.61 & $0.01 \pm 0.06$ & $\mathrm{P}$ \\
\hline X427/A & Tangaroa & 36.311 & 178.004 & 1781 & NMIMT & Tangaroa \#39, 6691 & & 2 & 59.26 & 2.63 & 0.67 & $0.06 \pm 0.07$ & $\mathrm{P}$ \\
\hline $\mathrm{X} 153 / 1$ & Ngatoro Rift & 36.260 & 177.300 & 2640 & NMIMT & 11574 Ngatoro Rift, 6702 & JBG00001C & 3 & 51.01 & 8.22 & 0.41 & $0.20 \pm 0.14$ & $\mathrm{P}$ \\
\hline $\mathrm{X} 158 / 1$ & Ngatoro Rift & 36.154 & 177.428 & 2300 & NMIMT & 11580 Ngatoro Rift, 6701 & & 3 & 52.04 & 7.05 & 0.52 & $0.60 \pm 0.24$ & $\mathrm{P}$ \\
\hline$X 185 / 1$ & Ngatoro Rift & 36.660 & 177.150 & 2810 & NMIMT & 11616 S. Ngatoro Rift, 6693 & JBG000016 & 3 & 52.41 & 4.86 & 0.55 & $0.35 \pm 0.22$ & $\mathrm{P}$ \\
\hline$X 168 / 1 A$ & Ngatoro Rift & 36.258 & 177.573 & 2960 & Menlo Park & $10 Z 0107$ & JBG000017 & 3 & 52.84 & 7.38 & 0.60 & $0.68 \pm 0.16$ & $\mathrm{R}$ \\
\hline $\mathrm{X690A}$ & Cross arc & 35.960 & 177.942 & 1805 & Menlo Park & $10 Z 0105$ & JBG000001 & 4 & 47.23 & 14.9 & 0.32 & $<0.11$ & I \\
\hline $\mathrm{X} 682$ & Cross arc & 35.968 & 178.023 & 1480 & Menlo Park & $10 Z 0106$ & JBG000007 & 4 & 51.13 & 8.17 & 0.42 & $<0.03$ & I \\
\hline X696A & Cross arc & 35.886 & 177.843 & 1680 & Menlo Park & $10 Z 0104$ & JBG00000J & 4 & 48.94 & 8.46 & 0.28 & $<0.07$ & I \\
\hline 015-04 & $\begin{array}{c}\text { Rapuhia } \\
\text { Ridge }\end{array}$ & 34.794 & 178.445 & 1910 & Menlo Park & $15 Z 0332$ & & 5 & 51.04 & 9.65 & 0.75 & $0.11 \pm 0.03$ & $\mathrm{P}$ \\
\hline 016-01 & $\begin{array}{l}\text { Rapuhia } \\
\text { Ridge }\end{array}$ & 34.798 & 178.442 & 1800 & Menlo Park & $15 Z 0334$ & & 5 & 49.60 & 9.99 & 0.49 & $0.05 \pm 0.05$ & $\mathrm{P}$ \\
\hline 012-01 & Gill & 34.623 & 178.379 & 1146 & Menlo Park & $15 Z 0319$ & & 5 & 47.91 & 9.30 & 0.46 & $1.19 \pm 0.04$ & $\mathrm{P}$ \\
\hline 011-04 & Gill & 34.607 & 178.389 & 1700 & Menlo Park & $15 Z 0318$ & & 5 & 51.22 & 8.07 & 0.75 & $0.97 \pm 0.03$ & $\mathrm{P}$ \\
\hline 011-A & Gill & 34.607 & 178.389 & 1700 & Wisconsin & UW93C37 & JBG00001K & 6 & 53.64 & 6.59 & 0.77 & $0.88 \pm 0.05$ & $P$ \\
\hline
\end{tabular}

Ages are: $P=$ plateau ages, I=Isochron ages, R=Recoil age (see Supplementary File for details). Supplementary File contains plateau and isochron ages and plots,

experimental data including K/Ca ratio, MSWDs, number of steps, and total gas age; along with an explanation of experimental methods and machine data for individual heating steps within each experiment. Results have been recalculated to a consistent fluence monitor age equivalent to Fish Canyon sanidine at $28.198 \mathrm{Ma}$ (Menlo Park)

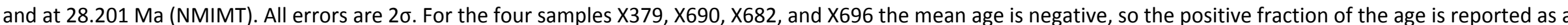
maximum value (i.e. $<x x \mathrm{Ma}$ ), calculated as the mean of the $2 \sigma$ error. IGSN numbers are given for those samples that have been assigned numbers.

Reference for geochemical analyses: 1, Gamble et al, 1997; 2, Wright \& Gamble unpublished data; 3, Gamble et al., 1993; 4, Todd et al., 2010; 5, Zohrab, 2017; 6, Todd et al., 2011. All geochemical data is reported as anhydrous, with Fe as FeOtotal (not reported here). 


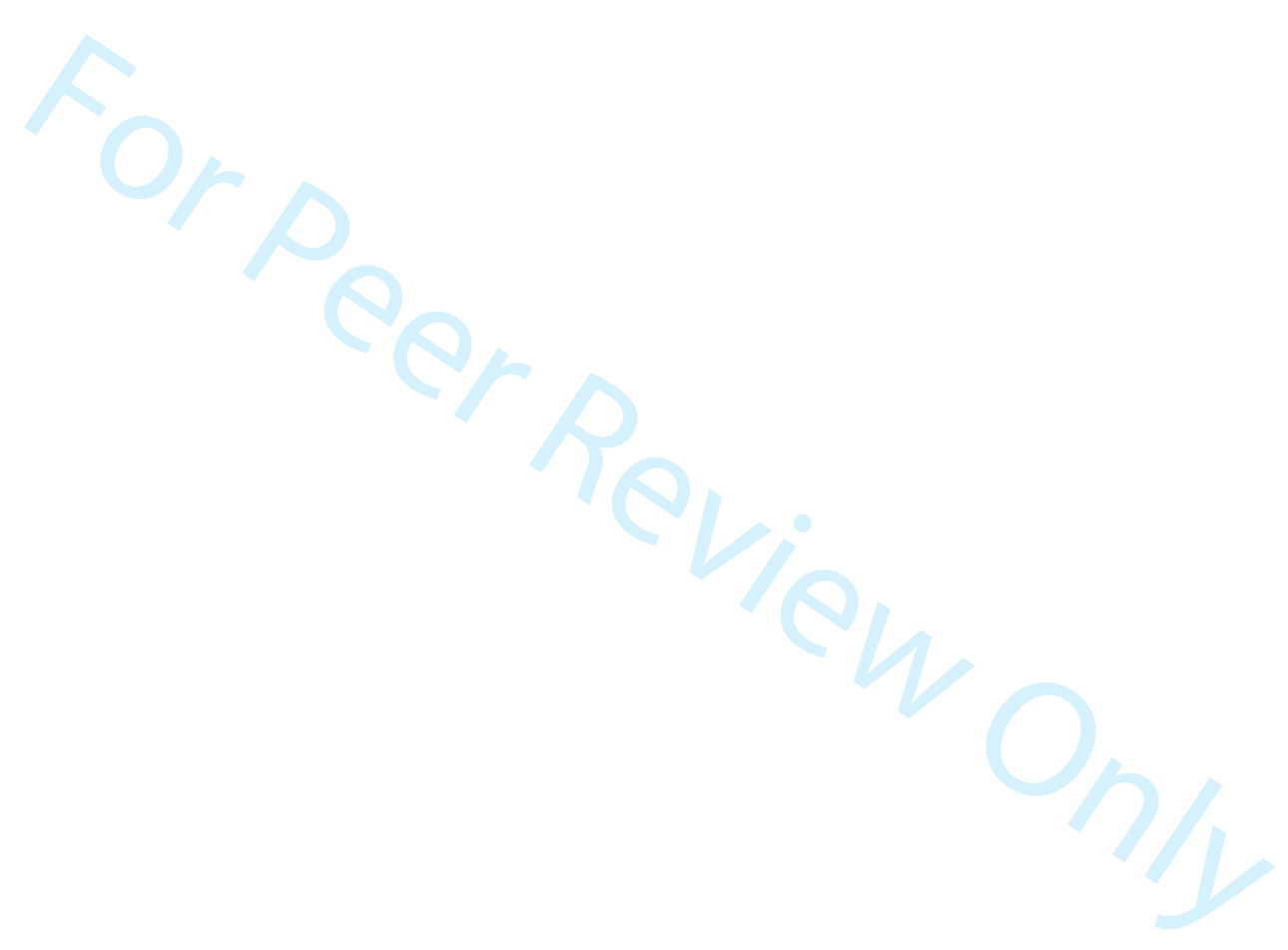




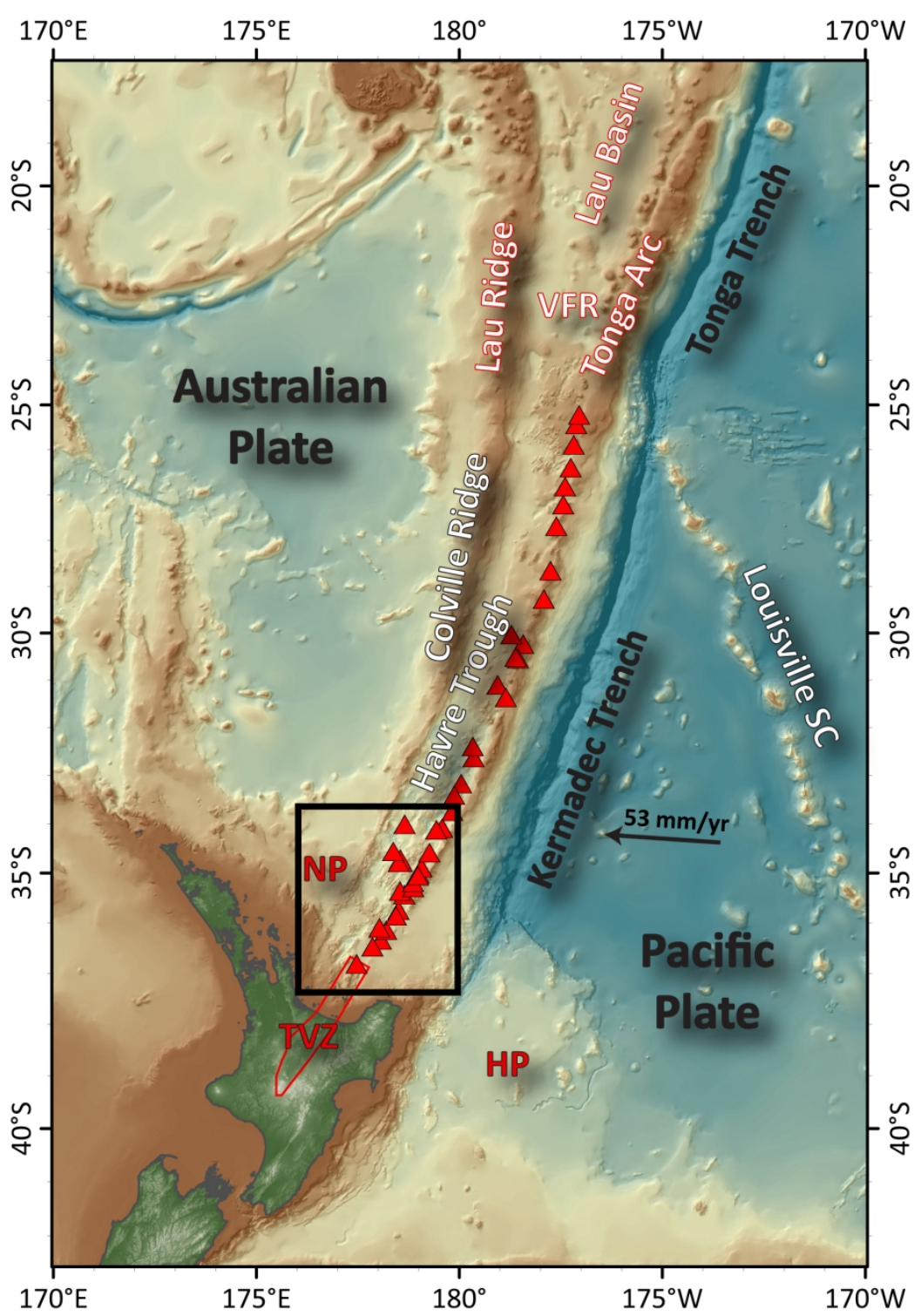

Figure 1: Tectonic setting of New Zealand and the SW Pacific highlighting the Kermadec Arc - Havre Trough (KAHT), the Tonga-Lau subduction system, and the Taupo Volcanic Zone (TVZ) of continental New Zealand (red outline). Black arrow is the relative motion of the Pacific Plate to a fixed Australian Plate for the southern KAHT region (DeMets et al., 2010). HP = Hikurangi Plateau, Louisville SC = Louisville Seamount Chain, NP $=$ Northland Plateau, VFR = Valu Fa Ridge. Red triangles denote oceanic volcanoes of the Kermadec Arc and Havre Trough, and the offshore TVZ (southernmost volcano, Whakatane). Highlighted area is that of Figure 2. 


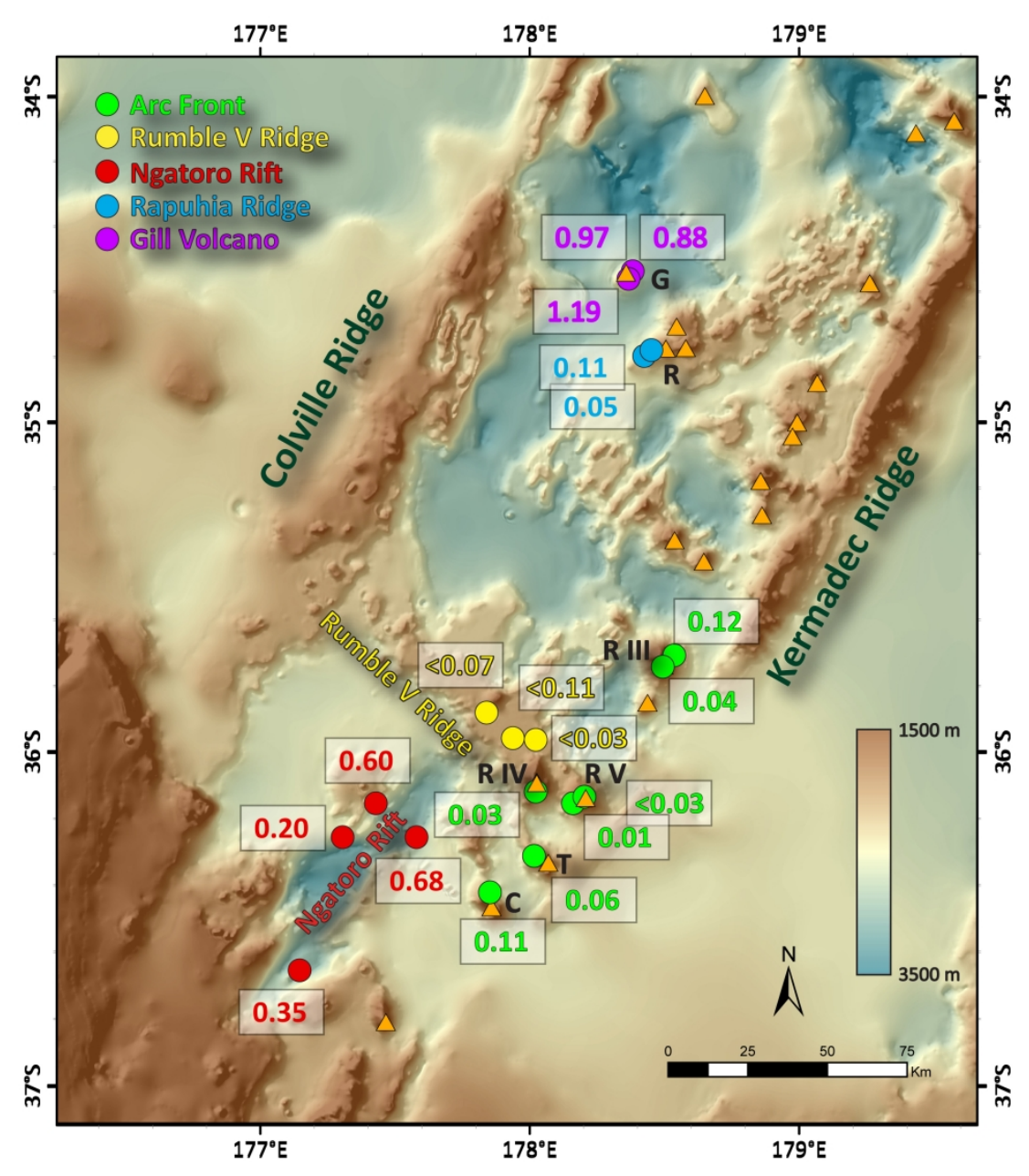

Figure 2: Bathymetric map of the southern KAHT system, bounded by the Colville Ridge to the west and the Kermadec Ridge to the east. Depths on the bathymetry scale are metres below sea level, with depths < $1500 \mathrm{~m}$ shown as $1500 \mathrm{~m}$ and depths > $3500 \mathrm{~m}$ shown as $3500 \mathrm{~m}$. Orange triangles are volcanoes: $\mathrm{C}=$ Clark, G = Gill, R = Rapuhia, RIII = Rumble III, RIV = Rumble IV, RV = Rumble V, T = Tangaroa. Numbers in boxes denote new Ar/Ar ages (Table 1).

$$
210 \times 296 \mathrm{~mm}(300 \times 300 \text { DPI })
$$




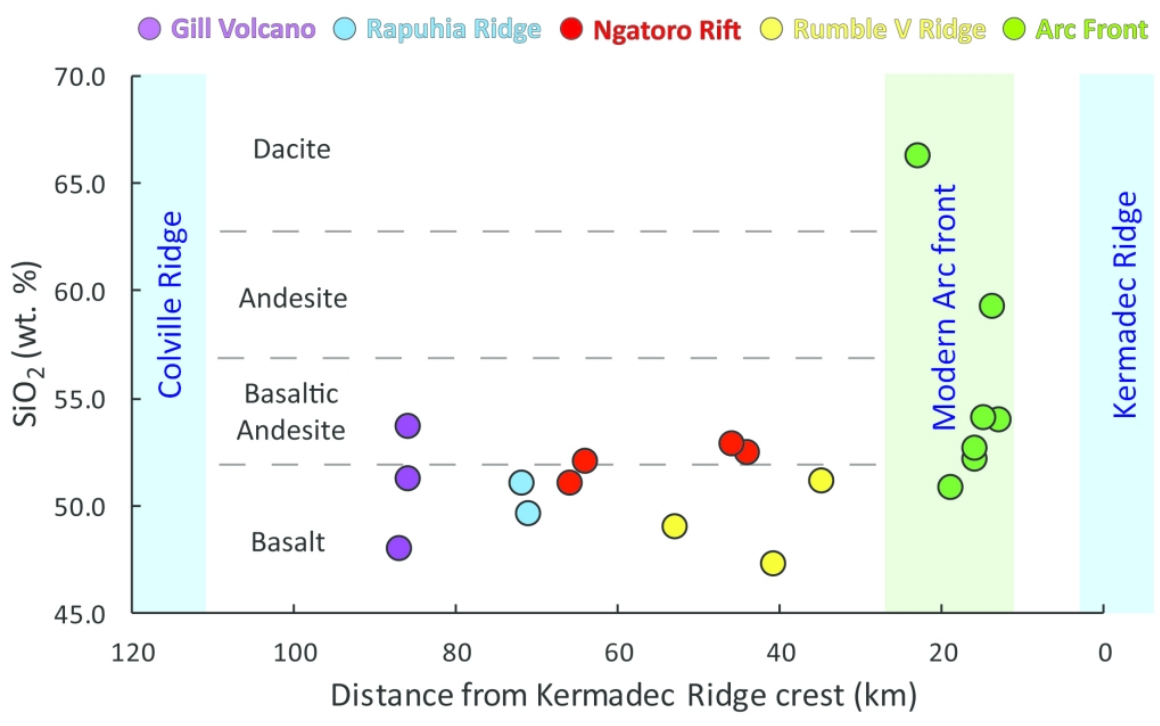

Figure 3: Silica content of samples analysed in this study with distance from the crest of the Kermadec Ridge.

$209 \times 126 \mathrm{~mm}(300 \times 300$ DPI $)$ 


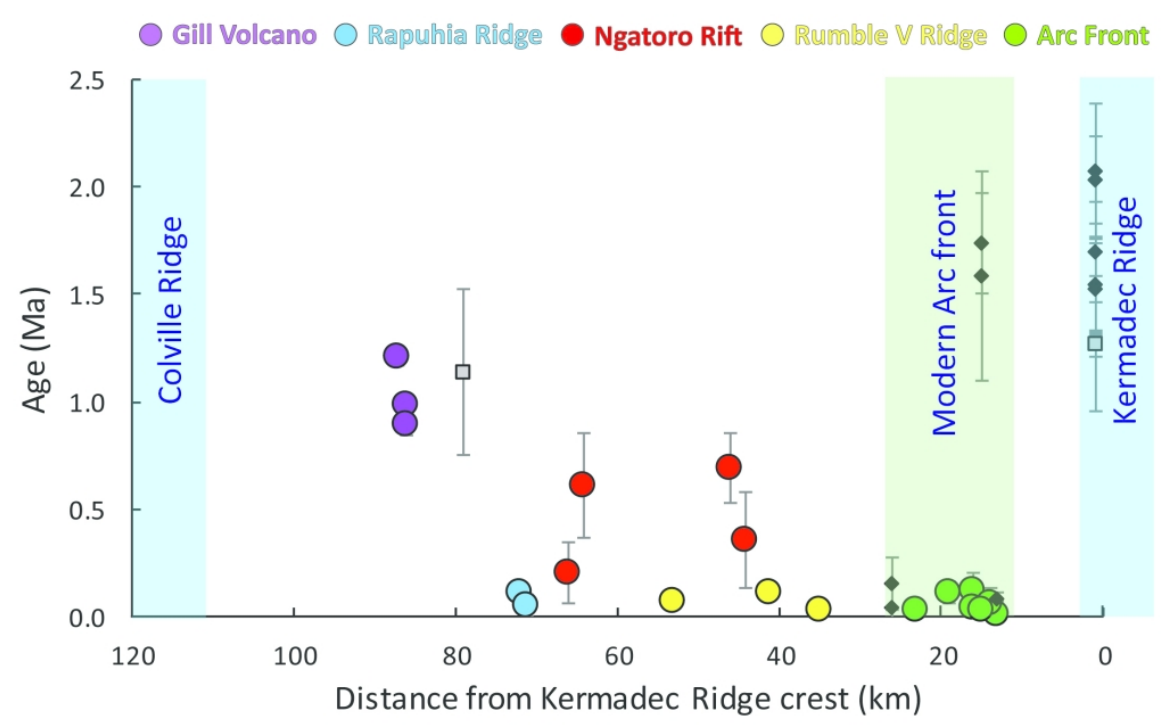

Figure 4: Ar/Ar ages of Havre Trough samples (Table 1) with distance from the Kermadec Ridge crest. Error bars show 2 sigma uncertainties. Black diamonds are K/Ar ages of Ballance et al. (1999) from Kermadec Ridge and Havre Trough samples at least $300 \mathrm{~km}$ north of samples presented here. Grey square at $80 \mathrm{~km}$ is an $\mathrm{Ar} / \mathrm{Ar}$ preferred age for a basalt from the Havre Trough (Mortimer et al., 2007). Grey square at $0 \mathrm{~km}$ is a U-Pb age of zircon from a tonalite from Raoul volcano (Mortimer et al., 2010), $600 \mathrm{~km}$ to the north of the study area, where the modern arc front sits on the Kermadec Ridge (Figure 1).

$209 \times 126 \mathrm{~mm}(300 \times 300 \mathrm{DPI})$ 